\title{
Designing Morphosyntax Material for EFL Students: Indonesian Case
}

\author{
Inayatul Mukarromah ${ }^{1}$, Sutjiati Beratha ${ }^{2}$, Ketut $_{\text {Artawa }}{ }^{2} \&$ Made Budiarsa $^{2}$ \\ ${ }^{1}$ Department of Education, IAIN Jember, Indonesia \\ ${ }^{2}$ Department of Linguistics, UDAYANA University, Indonesia \\ Correspondence: Inayatul Mukarromah, Department of Education, IAIN Jember, Indonesia.
}

Received: April 3, 2019 Accepted: May 13, 2019 Online Published: May 16, 2019

doi: 10.5539/elt.v12n6p140 URL: https://doi.org/10.5539/elt.v12n6p140

\begin{abstract}
Students' understanding about Morphosyntax is often low due to its complex processes. This study attempted to design a learning handout that would help students solve their writing problems particularly in Morphosyntax cases. This qualitative study was conducted at two Indonesian Universities, namely UNTAG Banyuwangi and IAIN Jember Indonesia. Six phases in Design Based Research (DBR) by Hoadley (2004) and four phases of DBR by Reeves (2012) were combined as the design of the research. Four classes with a total of 114 students participated and the lecturers of writing course and grammar course were involved. Following the mixed design of DBR by Hoadley and Reeves, this study produced a learning handout that, after tested at the second cycle, proved helpful to solve students' Morphosyntax problems especially in Writing Class. The students facing writing problems decreased averagely $35-40 \%$ after they learnt writing using the produced learning handout. In this case, the needs to master more on Morphosyntax to support their English proficiency skills especially in writing has been solved.
\end{abstract}

Keywords: morphosyntax, writing, material design

\section{Introduction}

Morphosyntax as part of microlinguistics is the amalgamation of morphology and syntax. It plays a pivotal role in writing class in that they are the central of language forms. In addition, Els (1984) mentions that Morphosyntax course is the bridge of language description to basic writing skill. Therefore, Morphosyntax mastery is believed to contribute positive pedagogical implications especially in foreign language learning. Badawi (2019) reports that EFL learners who comprehend the English word formations by combining prefixes, suffixes and roots are believed to acquire better achievement with their English than those who do not have such morphological knowledge. However, due to its complex morphological, lexical, and syntactical changes, EFL learners may encounter some problems to learn and employ them in their writing. Barra (2001) identified common areas of problems in EFL writing, such as spelling, applying of punctuations, content ambiguity and redundancy, based what to write on a mother tongue style, lacking of various types of writing presentation, lacking of content knowledge of written topics, lacking of content cohesiveness, failing to distinguish between facts and opinions, and failing to effectively communicate as expected. In Indonesian college situation, students learning English writing in their early year also find some writing difficulties (Sukarno, 2016). Therefore, any type of teaching material designed for improving their writing skill will be a great help for them. This study takes particular focus on the students' difficulty to understand morphosyntactic process and employ it to their writing resulting poor quality of writing. Due to its complication, Morphosyntax learning will have a big impact on their understanding of word formations in morphological or syntactical level. Given its significance in language mastery particularly in writing skill, it is therefore necessary that this study be conducted for the sake of their academic achievement.

In Indonesian situation, the low rate of university rankings and international publications imply some shortcomings and one of them is indicated to be the lack of English writing competency among students and academics. Despite the related issues, Indonesian Higher Education Institutions put a lot of efforts to escalate their scientific publication (Hermansyah, 2016). However, to the students and academics, it is frustrating for them to be demanded to publish their scientific works when they cannot write well due to some technical problems such as lack mastery of vocabularies and grammar. Hence, any mastery of linguistic knowledge related to writing is an essential support to their writing ability. One of them is to understand word formation involving 
morphological and syntactical process. Triggered by such problem especially in Indonesian context, I propose to design a writing material that will help Indonesian Higher students improve their writing skill. The design is particularly aimed at improving their understanding of morphological and syntactical complexities or so-called Morphosyntax competence. In conclusion, the purpose of this study was to develop new product of writing material designed specifically for Morphosyntax learning to improve students' writing skills.

\section{Review of Literature}

Writing and linguistics are closely tied up through the involvement of writer's grammar competence (Martinsen, 2000). Consequently, grammar must be taught in students' writing class (Weaver, 1996). EFL teachers, in this case, must analyze both writing and linguistic aspects in their language learning instructions (Harman, 2013). While EFL learners are required to have both skills for the successful writing, most of the students have low capability with their second or foreign language aspects, such as tenses, lexicon, syntax, and discourse (Luxin, 2013). Liddicoat's point of view about teaching is that teaching and learning do not only focus on what to teach but also how to teach especially in language education (2013). Hence, it is important for the EFL teachers teaching writing to take three aspects contributing to success of learning writing for their students, among others writing aspects, linguistic aspects, and methods of teaching both aspects.

Teaching grammar as part of teaching writing is strongly encouraged. Grammatical accuracy is one of the teaching activities that should be involved because it can have positive effects on the overall quality of students' writing (Richard, 2011). In addition, grammatical accuracy mastery is required in editing step of writing process. Editing refers to the process of detecting and correcting grammatical, lexical and other mechanical errors before publishing a final written product. One particular concern in grammatical accuracy involves morphology and syntax. Both of them interact in two ways. Syntactic constructs may form parts of complex words, and syntax in turns governs the use of morphological case marking on the word (Booij, 2007).

Grammar learning for students has regained its rightful place in the language curriculum. In Grammar learning, teaching involves any instructional technique that draws learners' attention to some specific grammatical forms in such a way that it helps them either to understand it metalinguistically and/or process it in comprehension and/or production so that, they can internalize it (Ellis, 2006). It means that teaching grammar plays very prominent role in supporting students' writing competence in various ways, such as word formation, phrase, clause and sentence.

Writing competence needs grammar competence and grammar competence needs the ability of morphological and syntactical formation. The ability of students to arrange word into phrase and clause are called Morphosyntax competence. Morphosyntax combines the two language forms, morphology and syntax, which make up a grammatical system. First, there is morphology, which is simply word formation, or how the parts of a word fit together, and then syntax, or the rules governing how words are then formed into clauses or sentences (Fiona, 2015). Morphosyntax competence can improve students' writing as it involves morphology, vocabulary, syntax, and grammar competence. In short, Morphosyntax is a term in linguistics used to refer to grammatical categories or properties for whose dysfunction criteria of morphology and syntax both apply, as in describing the characteristics of words (Cristal, 1980).

\section{Research Method}

This qualitative study was conducted at two Indonesian Universities, namely UNTAG Banyuwangi and IAIN Jember Indonesia. In this study, Six phases in design based research (DBR) by Hoadley (2004) and four phases by Reeves (2012) were combined as the design of the research.

The reasons for choosing DBR in this study is because DBR is an effective research approach used as an intervention in education (Van den Akker et al., 2006) that encourages a researcher to use survey and interviews to see things in a natural setting and aimed at building theory (Kelly, 20014). In addition, DBR is able to solve the problems that occur in the field in a more efficient, faster and better result (Reeves, 2012 \& Hoadley, 2004). The mixed design of DBR in this study allows the researcher to create useful products and effective theory for solving individual and collective problems in writing. 


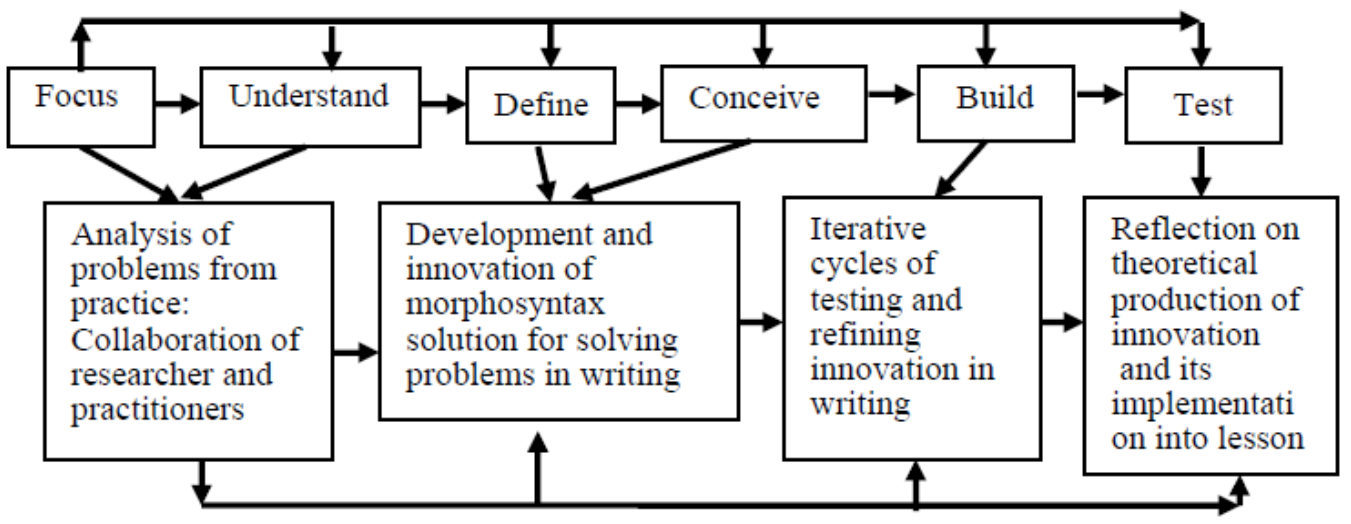

Figure 1. Design process by Hoadley (2004) combined with Reeve's (2012)

The design phases in DBR are not carried out in a linear sequence but rather iteratively. In the focus phase, the audience, topic, and scope of the project are carefully observed. The audience specifies whom the product serves, including learners, teachers, and school stakeholders affected. In the understand phase, the students, domains, contexts and existing solutions are examined to investigate the problem through empirical methods and secondary sources, and synthesized the findings into a form that can be easily used later in the process. In the define phase, goals and assessments are situated. Buchanan (1992) explains that defining means converting an indeterminate problem, which has no solution, into a determinate problem that can be solved. In the conceive phase, a plan for the solution is attentively designed based on the intended goal. In the build phase, the designer implements the solution. Once a design has been envisaged, the designer can implement the design in a form that can be used. In the test phase, the designer evaluates the efficacy of the solution. Iterative user-testing involves testing successive versions of the design at increasing levels of reliability.

\section{Result and Discussion}

The supreme goal of design-based research is to assemble a stronger affiliation between educational research and real world problems. The pivotal role is on an iterative research process that does not just assess an innovative product or intervention, but thoroughly endeavors to refine the innovation while also producing design principles that can direct similar research and development attempts. The end goal of this study is therefore a writing material handout designed for learning Morphosyntax. The design produced in this study is expected to be able to provide benefits for some parties especially lecturers and students. Moreover, the teaching material products will be an additional support to the existing curriculum and syllabi. Teaching material would have a great impact on the quality of learning in the classroom because teaching material is an effective way of reflecting learning (Richard \& Renandya, 2002). Meanwhile Tomlinson (2007) stated that teaching material was designed based on teaching acquisition and development, so teaching materials could be a source for mediating and facilitating teaching and learning. The learning handout produced from this study entitles "Better Writing Through Morphosyntax". This writing material is the end product of this research design process that has been determined to help lecturers in teaching and improving students' ability in writing. The collaboration between the two design based research resulted in a DBR through the stages of the process as follows:

\subsection{Focus Phase as the Analysis of the Practical Problems}

In this phase, the researcher determined third semester students at IAIN Jember and UNTAG Banyuwangi Indonesia in the academic year 2017 as the research subjects. Four classes with a total of 114 students participated in this study. While the lecturers involved were those who taught writing and grammar. The research topic focused on writing development especially in Morphosyntax mastery. The researcher analyzed the problems that occurred in the writing class and the needs of students in the two institutions. The result of the analysis was that $85 \%$ of students involved committed grammatical errors particularly Morphosyntax errors in their writing and urged the need to deepen the material to improve their writing skills. Based on the previous findings, the researcher helped by the lecturers gave a writing test at both universities to uncover students' real problems with their writing. After an indepth analysis through examining the academic documents, such as curriculum, syllabi, and lesson plans, the researcher finally chose four classes of third semester students taking Writing Class to be involved because the teaching material products would be a more appropriate solution to solve their problem. 
The result of the students' writing from three classes at IAIN Jember and one class at UNTAG Banyuwangi showed that $68 \%$ of students in class TBI 1, $62 \%$ of students in class TBI 2, $60 \%$ of students in Class TB 3, and $70 \%$ of students in class A needed improvement with their writing skill. They committed errors at Morphosyntax level. It implied that $62 \%$ to $70 \%$ of third semester students at both colleges in the academic year of 2017 had to be treated in arranging word into phrase and clause (moprphosyntax cases). Therefore, specific material designed for learning Morphosyntax applied in writing was urgently required and it was for solving such problem that this study was conducted.

\subsection{Understand Phase Analysis of the Practical Problems}

Before designing a course material, it is necessary to consider some points, such as the basic competencies, materials, references, course description, concept map, course objectives, competencies and achievement indicators, timeline, assessment, and teaching strategies applied in these universities. At this stage the researcher conducted an empirical study of the data obtained from observations or surveys, interviews, questionnaires, student assignments, and also theories related to language learning and teaching, teaching material, Morphosyntax, grammar, vocabulary and writing to further explore the projects being developed. The results of the empirical and theoretical analysis, it was urgently required that a new solution for solving students' writing problem be found. Based those mentioned reasons, the researcher made an attempt to create a teaching material product to improve student writing skills with particular attention on Morphosyntax mastery.

As mentioned before that the first thing to cover in this phase was finding out the students' needs in improving their writing. The survey of needs analysis revealed that $85 \%$ of students at IAIN Jember and UNTAG Banyuwangi needed to develop better writing skill. There were around $60 \%$ to $85 \%$ of students who did not understand the correct writing rules. In addition, $80 \%$ of stakeholders and lecturers also stated the same thing about the need for an in-depth material to develop students' writing skills. Before the researcher developed and innovated a learning material, the researcher gave writing tests to students. The results of the student's writing were analyzed and revealed inflection, word formation, phrase, and clause problems. Based on those findings, the researcher attempted to design and create innovations in order to solve students' problems in writing.

\subsection{Define the Phase of Development and Innovation for the Problem Solving}

At this stage the researcher determined the objectives of research, among others: (1) knowing students' writing skill from the results of morphosyntactic analysis (2), making product in the form of writing materials through Morphosyntax by referring to the curriculum in universities where the researcher conducted the research, so that the expected product would be beneficial for the both institutions and other universities as well, (3) knowing the results of students' writing skills who got Morphosyntax-based learning, (4) knowing how helpful DBR was as a tool to help design educational product, and (5) produceing an academic text like a learning handout used for the material book.

\subsection{Conceive as Development and Innovation of Morphosyntax Solution for Solving Problem in Writing}

This research focused on language teaching and learning in two institutions of higher education namely IAIN Jember and UNTAG Banyuwangi Indonesia. In this language learning, the lecturers' assignments were mediating the learning process, providing facilities for the learning process, and giving evaluation. These three elements played as the core of the pedagogy. In addition to those three cores, it was important for the lecturers to produce teaching materials according to the skills needed by students. Based on the findings of the empirical evidences and following DBR phases, this study proposed new product in the form of instructional materials to improve students' writing skills especially in Morphosyntax mastery. This learning handout was aimed for students at the third semester who participated in the Paragraph Writing Class.

\subsection{Build as Reflection on Theoretical Production of Innovation and Implementation into Lessons}

At this stage the new product has been physically printed out as a learning handout of Morphosyntax learning material. The most important thing in this stage was implementing the teaching material product to students in class for 8 meetings and the test the students to know the progress.

\subsection{Test and Iterative of Testing and Refining Innovation in Writing}

In this phase, the researcher carried the second test to know the impact of the product to students' writing mastery. By comparing the results of the first test and the second test, the benefit of the product could then be measured. The second test revealed that the students' writing from three classes at IAIN Jember and one class at UNTAG Banyuwangi showed significant improvement than the first test. Now only $25 \%$ of students in class TBI $1,32 \%$ of students in class TBI 2, 30\% of students in Class TB 3, and 30\% of students in class A were still in need of improvement in their writing. Accordingly, it can be inferred that $70 \%$ to $75 \%$ of third semester students 
at both colleges in the academic year of 2017 have shown improvement of writing especially in arranging word into phrase and clause (moprphosyntax cases) to their paragraph writing. Therefore, the material produced in this study for learning Morphosyntax in writing was concluded helpful to help students solve their writing problems. Other than its usefulness, evaluation on the product is indeed necessary, in this case, to improve the product so that the shortcomings found in this study can be further covered.

\section{Conclusion}

Morphosyntax as part of microlinguistics is the amalgamation of morphology and syntax. In writing class, the theory of morphological processes such as affixation, word order, and rewriting rules is the basic skill of writing. It is aimed at developing students' writing skills. However, students' understanding about Morphosyntax is often low due to its complexity of the processes. The first writing test given to students in this study proved that proposition. Students had problems in Morphosyntax cases. They stated that they needed to deepen their mastery in particular areas of writing particularly in morphological and syntactical processes. In collaboration with the writing lecturers, the researcher attempted to design a learning handout particularly for helping students with Morphosyntax problems. Following the mixed design of DBR by Hoadley and Reeves, this study produced a learning handout, after tested at the second cycle, proved helpful to solve students' problems. The students facing writing problems decreased averagely $35-40 \%$ after they learnt writing using the learning handout. In this case, the needs to master more on vocabulary and sentence pattern to support their English proficiency skills especially in writing has been solved. Improvement on the product is always needed due to different context of situation along the time in the classroom.

\section{References}

Badawi, M. F. A. (2019). The Effect of Explicit English Morphology Instruction on EFL Secondary School Students' Morphological Awareness and Reading Comprehension. English Language Teaching, 12(4). https://doi.org/10.5539/elt.v12n4p166

Barra, A. (2001). Writing: Reflection and Research may Increase Teacher Understanding. Retrieved from $\mathrm{http} / / / \mathrm{e}$.usia.gov/forum $/ \mathrm{htm}$

Boiij. (2007). The Grammar of Words. New York: Oxford University Press. https://doi.org/10.1093/acprof:oso/ 9780199226245.001.0001

Buchanan, R. (1992). Wicked Problems in Design Thinking. Design Issues, 8(2), 5-21. https://doi.org/10.2307/ 1511637

Crystal, D. (1980). A First Dictionary of Linguistic and Phonetics. London: Andre Deutch.

Ellis, R. (2006). Current Issues in the Teaching of Grammar: an SLA Perspective. TESOL, Quarterly, 40(1), 83-107. https://doi.org/10.2307/40264512

Els, T. V. (1984). Applied Linguistics and the Learning and Teaching of Foreign Languages. London: Edward Arnold.

Fiona. (2015). Why do Linguistic. UK: Bloomsbury Publishing Plc.

Harman. (2013). Literary Intertextuality in Genre-Based Pedagogies: Building Lexical Cohesion in Fifth-grade L2 Writing. Journal Second Language Writing, 22, 125-140. https://doi.org/10.1016/j.jslw.2013.03.006

Hermansyah, A. (2016). Indonesia Lags behind in Scientific Publications: Expert.

Hoadley, C. M. (2004). Methodological Alignment in Desain Based Reserach. Educational Psychologist, 39(4), 203-212. https://doi.org/10.1207/s15326985ep3904_2

Kelly, A. E. (2004). Design research in education: Yes, but is it methodological? The Journal of the Learning Sciences, 13(1), 115-128. https://doi.org/10.1207/s15327809j1s1301_6

Liddicoat, A. J. \& Angela, S. (2013). Intercultural Language Teaching and Learning. Oxford: Wiley-Blackwell. https://doi.org/10.1002/9781118482070

Luxin, Y. (2014). A Community of Practice of Teaching English Writing in a Chinese University.

Martinsen, A. (2000). The tower of Babel and the Teaching of Grammar: Writing Instruction for a New Century. English Journal, 90(1), 122-126. https://doi.org/10.2307/821742

McKenney, S., \& Reeves, T. (2012). Conducting Education Design Research. London: Routledge

Richard, J. C., \& Renandya, W. A. (Eds). (2002). Methodology in Language Teaching: An Anthology of Current Prcatice. Cambridge; Cambridge University Press. https://doi.org/10.1017/CBO9780511667190 
Richard. (2011). Methodology in Language Teaching. USA: Cambridge University Press.

Sukarno. (2016). The Analysis of Grammatical Errors of First Year Students' Essays. A Journal of Culture, English Language Teaching \& Literature, 16(1). https://doi.org/10.24167/celt.v16i1.488

Tomlinson, B. (Ed). (2007). Language Acquisition and Development: Studies of First and Other Language Learners. London: Continuum.

Van den Akker, J., Gravemeijer, K., McKenney, S., \& Nieveen, N. (2006). Educational Design Research. Abingdon, Oxon: Taylor \& Francis. https://doi.org/10.4324/9780203088364

Weaver, C. (1996).Teaching grammar in the context of writing. English Journal, 85(7), 15-24. https://doi.org/10.2307/820502

\section{Copyrights}

Copyright for this article is retained by the author(s), with first publication rights granted to the journal.

This is an open-access article distributed under the terms and conditions of the Creative Commons Attribution license (http://creativecommons.org/licenses/by/4.0/). 